\title{
PROTECTING CHILD WITNESSES: NEW DEVELOPMENTS AND IMPLICATIONS FOR SOCIAL WORKERS
}

\section{Carmel Matthias}

\section{INTRODUCTION}

Social workers often work with child clients who need to give evidence in court. Unfortunately these children are vulnerable to secondary systemic abuse. Feelings of intimidation at court may also adversely affect the accuracy of their evidence, leading to an inappropriate outcome (Hall, 2009; Muller \& Van der Merwe, 2005). Many countries have therefore introduced technology-based protective measures to reduce the stress experienced by child witnesses. These include pre-recorded evidence, separate-venue testimony with a video link, and intermediaries. In South Africa it is important that social workers have a good understanding of the legal framework. They are often in a position to provide pre-court assessments motivating for protective measures. They may also be called upon to give expert evidence in court on whether a particular child requires a separate venue or an intermediary.

Social workers may alternatively be involved by serving as intermediaries themselves. Intermediaries act as a communication conduit when a child witness is being questioned in court. Instead of an opposing party or lawyer being able to address questions directly to the child, they are conveyed to the intermediary. The intermediary then communicates them to the child in non-threatening, age-appropriate language. The child's replies are also conveyed through the intermediary. So far in South Africa intermediaries have been used mainly for criminal cases, and particularly ones involving sexual offences against children. Internationally it has been recognised that sexual offence victims are amongst the most vulnerable of all child witnesses (Hall, 2009).

This article first explains and evaluates the legislation which provides for protective measures in South African criminal cases. It then analyses two important cases. In the first the High Court found in 2008 that there was inadequate protection for child witnesses. In the second the protective measures were assessed for the first time by South Africa's highest court, the Constitutional Court, in 2009. In the third part of the article another significant and related development is considered. Intermediaries have been introduced to children's courts as a result of the Children's Act 38 of 2005, which came into force on 1 April 2010. The questions of whether a correct approach has been adopted in the Act and the implications of recent case law for children's court proceedings are explored. The final part of the article offers some conclusions on whether the law has developed sufficiently and makes recommendations on how social workers can make the best possible use of it.

\section{LEGISLATION PROVIDING FOR PROTECTIVE MEASURES IN CRIMINAL CASES}

In 1991 Section 170A was introduced into the Criminal Procedure Act 51 of 1977. Since this came into force in 1993, it has been possible for certain child witnesses in criminal cases to be assisted by intermediaries. They do so via electronic devices and closed-circuit television viewed in the courtroom. A child is defined for this purpose as any person under 18 years of age. A particularly important aspect is the legal grounds for appointment of an intermediary. In terms of section $170 \mathrm{~A}(1)$ : 
Whenever criminal proceedings are pending before any court and if it appears to such court that it would expose any witness under the age of eighteen years to undue mental stress or suffering if he or she testifies at such proceedings, the court may subject to subsection (4) appoint a competent person as an intermediary in order to enable such witness to give his or her evidence through that intermediary [emphasis added].

In addition to the appointment of an intermediary, the court may also order that the witness give evidence in an informally arranged room provided with electronic or other devices (section 170A(3)). Persons who can serve as intermediaries are medical practitioners with a specialisation in paediatrics or psychiatry, family counsellors, child care workers with a twoyear course in child and youth care work, registered social workers with at least two years experience, teachers with four years experience, and clinical, educational or counselling psychologists (GG 15024 of July 1993 as amended by GG 17882 of 28 February 1997, and amended by GG 22435 of 2 July 2001).

Section $170 \mathrm{~A}(2)(\mathrm{b})$ provides that if an intermediary has been appointed he/she must "convey the general purport of any question" and that all examination and cross-examination of the child witness must take place through the intermediary. The intermediary will therefore listen on earphones to a question directed to the child and then communicate it to the child. As noted by Jonker and Swanzen (2007:6): "The intermediary has the duty of buffering aggression and intimidation...."

Section 170A has been criticised by some commentators because it is discretionary and therefore does not provide an absolute right for all child witnesses to have an intermediary (Muller \& Tait, 1999; Simon, 2006). A further limitation is that undue mental stress or suffering by the witness has to be proved as a ground. Therefore an expert witness, which usually includes social workers or psychologists, may be needed to testify about what the child would be likely to experience in open court (Mellis, n.d.). Even if the likelihood of undue mental stress or suffering is proved, the presiding officer still has a choice. As can be seen from section 170A as quoted above, he or she 'may' choose whether to allow the appointment of an intermediary. This wide discretion has made it easy to avoid the extra procedural step of appointing an intermediary. Muller and Van der Merwe (2005:42) state that "Despite the fact that judicial officers are inherently authorised to take control of court proceedings, many still play a passive role and remain aloof due to their fear of being seen to be partial". Inconsistent applications have resulted because of the discretion and this is a matter of concern. Also, undue mental stress or suffering is a vague concept which is not defined (Muller \& Tait, 1999; Schutte, 2005).

Section 158 of the Criminal Procedure Act 51 of 1977 was enacted in 1996. It provides for witnesses to give evidence "by means of closed-circuit television or similar electronic media". This may be requested by the public prosecutor or the witness, or ordered by the court. The court may grant requests subject to "available or obtainable" facilities and to "prevent the likelihood that prejudice or harm might result to any person if he or she testifies or is present at such proceedings". This effectively provides for a second protective measure, which entails giving evidence from a separate venue without the assistance of an intermediary. The South African Law Commission (2002) criticised the available or obtainable facilities limitation. They recommended an amendment to the legislation to enable transfers of cases to courts with available facilities. Whilst section 158 protects witnesses from the presence of the accused, it does not shield them from aggressive cross-examination and confusing legal language. 
The original legislation has thus not been optimally effective in protecting children.

\section{Amendments to the legislation}

The inadequacy of the legislation was recognised and in 2007 it was amended. The Criminal Law (Sexual Offences and Related Matters) Amendment Act 32 of 2007 (hereafter the 2007 Amendments) extended the grounds for the appointment of intermediaries. Now not only persons under 18 years of age, but also persons "under the biological and mental age of eighteen years" exposed to undue mental stress or suffering are eligible to receive assistance from intermediaries.

Also, the 2007 Amendments added subsections 158(5) and 170A(7) to the Criminal Procedure Act. These provide, respectively, that criminal courts must immediately give reasons for refusing requests by the prosecution to provide evidence via electronic means from a separate room or to use an intermediary. A limitation is that the 2007 Amendments only impose the duty to give immediate reasons where it is a child complainant and not other child witnesses. Also, the child must be under the age of 14. The Amendments do not address the main criticisms of commentators. The wide discretion for presiding officers and the vague legal grounds remain. Therefore, the problem of a lack of consistency in allowing protective measures was not addressed.

In the High Court case of $S v$ Mokoena; $S v$ Phaswane (2008) the constitutional validity of the sections of the Criminal Procedure Act providing for protective measures came under judicial scrutiny. The case subsequently went up to the Constitutional Court. Here, it was reported as Director of Public Prosecutions, Transvaal $v$ Minister for Justice and Constitutional Development and Others (2009 - hereafter the Director of Public Prosecutions case). As a result of these judgments, the law on protective measures has been clarified and developed. Each case will be discussed separately.

\section{RECENT CASE LAW}

\section{The High Court Case}

In $S$ v Mokoena; $S v$ Phaswane criminal sentences in two similar magistrates' court cases were considered together by the High Court judge, Bertelsmann J. The first accused had raped an 11year-old child and the second had raped a 13-year-old. In the first case an intermediary for the child complainant had been appointed by the magistrate, based on an assessment by a social worker. Yet in the second case the High Court found that the question of whether the complainant needed an intermediary had not even been considered. He stated "The impression is created that there was no intermediary available..., so that the court, the prosecution and the defence regarded it as useless to investigate whether a 13-year-old might be in need of such assistance" (para 4(i)).

The High Court reacted strongly to the long-standing problem of inconsistency in decisions by lower magistrates' courts. It concluded that the wide discretion which section 170A leaves to courts in considering whether to allow intermediaries renders it unconstitutional. The judge reasoned that the resulting lack of uniformity for child witnesses in similar circumstances is inconsistent with section 28(2) of the Constitution. Section 28(2) requires that the best interests of children be treated as paramount. He stated that the requirement in section 170A for a child witness to be exposed at court to "undue" stress and suffering before an intermediary may be appointed: 
... places a limitation upon the best interests of the child that is neither rational nor justifiable....To demand an extraordinary measure of stress or anguish before the assistance of an intermediary can be called upon clearly discriminates against the child and is constitutionally untenable (para 79).

With reference to the 2007 Amendments, the High Court had concerns about subsections $158(5)$ and $170 \mathrm{~A}(7)$. As mentioned above, these require courts to immediately provide reasons when refusing applications for protective measures for complainants aged below 14 . Bertelsmann $\mathbf{J}$ reasoned that this produced an illogical age discrimination against older children, because they were not provided with the same right. The judge also found the Amendment irrational because it protected complainants, but not other child witnesses (para 83 ). He concluded that subsections $158(5)$ and $170 \mathrm{~A}(7)$ created such a degree of discrimination between children that they were unconstitutional. This meant that they were no longer valid law.

The High Court's finding of invalidity removed key parts of the law. Not surprisingly, therefore, the Minister of Justice and Constitutional Development and other interested parties reacted by seeking clarity from a higher forum, the Constitutional Court.

\section{The Constitutional Court Case}

In a complete reversal of the High Court judgment, the Constitutional Court in the Director of Public Prosecutions case concluded that sections 158(5) and 170A must continue to stand because they are constitutional. Ngcobo J (subsequently appointed Chief Justice) wrote the majority judgment for the Constitutional Court. The Court decided that the High Court was incorrect in concluding that a child witness must first be exposed to undue mental stress or suffering. Rather, the proactive intention is to prevent such exposure (para 110). The Constitutional Court then indicated the procedure that courts must follow. It stated that all child witnesses in criminal cases must in future be properly assessed before court hearings commence. If this assessment indicates that an intermediary is needed, then the prosecution must apply for one at the very beginning of the trial (para 111).

Particularly important is a further ruling by the Constitutional Court that magistrates or judges themselves must inquire into the need for appointment of a protective measure, if the prosecutor does not raise the issue and a child witness is to appear. Presiding officers must apply the best interests of the child principle and weigh up relevant evidence when conducting such inquiries. According to the Constitutional Court:

What is required of the judicial officer is to consider whether, on the evidence presented to him or her, viewed in the light of the objectives of the constitution and the subsection, it is in the best interests of the child for an intermediary to be appointed (para 115).

This ruling is a very significant development. It means that whenever child witnesses or older vulnerable witnesses are called in criminal cases, the possible need for a separate venue and/or intermediary must be canvassed. Prosecutors and courts will no longer be able to avoid this simply because it is not easy or convenient to obtain the resources required. It would even appear that presiding officers must obtain sufficient evidence on the issue if it is not already available. The Constitutional Court has therefore extended protective requirements by means of this important procedural directive.

The Constitutional Court went on to consider the High Court's finding that section 170A is unconstitutional because it confers a completely unconstrained discretion on judicial officers. 
Ngcobo $\mathrm{J}$ held that on this aspect the section is once again entirely valid. Rather than accepting the prevailing view that appointment of intermediaries should be compulsory for all child witnesses, he decided that a broad discretion is in fact useful. It "enables courts, on a case-bycase basis, to determine whether the services of an intermediary are required" (para 124). It allowed for a flexible weighing up of relevant criteria such as a child witnesses' age, maturity, degree of independence, feelings and wishes, and "the nature of the offence" (para 124). He noted that some older children might not even want an intermediary. Hence, the discretion was needed to allow flexibility in decision making. This was essential for ensuring that the best interests of child witnesses are paramount in each case, as required by section 28(2) of the Constitution (paras $125 \& 129$ ). He reasoned that problems with section 170A are caused, not by the provision itself, "but in the manner in which it is interpreted and implemented" (para 131). He concluded that what is therefore required is proper training in law and procedure of presiding officers and prosecutors (para 131). The Constitutional Court singled out training of prosecutors as particularly important, because it is they who must decide whether to bring an application for a protective measure (Muller \& Van Der Merwe (2004) on the training required).

Turning to the 2007 Amendments, the Constitutional Court decided that "Sections 158(5) and $\mathrm{S} 170 \mathrm{~A}(7)$ are capable of being read in a manner that is consistent with the Constitution" (para 159). They must be interpreted as not changing a general pre-existing requirement that a criminal court must give reasons for refusing to allow the use of CCTV or an intermediary in respect of all children below 18 and not merely those below 14 (para 159). It should do so as it would for any other important decision. As Ngcobo J reasoned:

The issue is one of emphasis rather than one of exclusion. What the subsections emphasise is that the younger the child, the more the need exists for protection. Selecting the age of 14 years may perhaps be perceived as arbitrary. So are all choices relating to age. This, however, does not detract from the fact that the subsections recognise that younger children may need protection more than older children. As pointed out earlier the protection given to children must be appropriate to their age, level of maturity and unique needs. These sections recognise this. They also recognise that vulnerability decreases with age (para 160).

Ngcobo J thus decided that the purpose of the 2007 Amendment was simply to give greater protection to younger children. He concluded it is "neither irrational nor unfair" for judicial officers to have to give reasons "immediately upon refusal" for children under 14, and only much later when presenting their final judgment for older children (para 161). He went so far as to praise the Amendments for usefully reminding "presiding officers of the greater vulnerability of younger children". Thus he concluded that the High Court was wrong in finding subsections $158(5)$ and 170A(7) unconstitutional.

\section{THE CHILDREN'S ACT 38 OF 2005}

Aside from the first-ever detailed assessment of legal protective measures by the Constitutional Court, another significant development is extension of the use of intermediaries beyond criminal matters to a wide range of care and parental responsibilities cases dealt with by the children's courts. The children involved have often been subjected to sexual offences, other abuse or neglect. This means that they fall into the highest vulnerability category (Hall, 2009) and are just as likely to need protective measures as child witnesses in criminal courts. The introduction of intermediaries into children's courts is in terms of section 61(2) of the 
Children's Act 38 of 2005. The Act and regulations published on 1 April 2010 represent a substantial initiative aimed at radically modernising parenting and child law in South Africa.

Section 61(2) reads:

A child who is a party or a witness in a matter before a children's court must be questioned through an intermediary as provided for in section 170A of the Criminal Procedure Act, 1977 (Act No. 51 of 1977) if the court finds that this would be in the best interests of that child.

As can be seen, it is possible to appoint an intermediary to assist a vulnerable child in any of the matters that come before children's courts in terms of the new legislation. These include a wide range of cases involving parental responsibilities, mandatory alternative care, and adoption - including inter-country adoption, parental abduction, child trafficking and surrogate motherhood.

The ability to appoint intermediaries for child witnesses is a significant step forward in the children's courts. However, the method of incorporation by using section $170 \mathrm{~A}$ of the Criminal Procedure Act means that the vague ground of "undue mental stress or suffering" will have to be applied before appointing an intermediary in a children's court case. The wide discretion for presiding officers, even where there is undue stress or suffering (as discussed above), will also be imported. In the children's courts, as in the criminal courts, the extent to which magistrates feel motivated to take the extra steps required to appoint intermediaries will be a crucial factor. This will certainly impact on how many children actually benefit. This raises the question of whether the Director of Public Prosecutions case will have to be followed in children's courts. Of particular importance is whether the ruling applies that, if the necessity for an intermediary is not sufficiently canvassed by the parties, then the magistrate must conduct an inquiry and even solicit additional evidence, if required.

One interpretation would be that, because Director of Public Prosecutions was a criminal matter, it doesn't apply to children's courts. A contrary view would be that it does apply because the court was specifically considering how section 170A of the Criminal Procedure Act must be implemented. And section 61(2) of the Children's Act expressly incorporates that provision into children's court procedures. It is this second and broader interpretation which should be preferred. What was really at issue was sufficient protection for child witnesses. For children giving evidence, exactly the same challenges can arise in children's courts as in criminal courts. For here also a child may be too terrified to provide accurate testimony when being cross-examined in close physical proximity to an abusive adult. It is to be hoped, therefore, that the Constitutional Court's instruction that the question of an intermediary must be properly dealt with in every case will be extended to children's courts. Since social workers will often have full party status in children's courts (Children's Act, 2005: section 1), and not merely expert witness status as in the past, they will be in a strong position to request intermediaries.

\section{DISCUSSION}

The two major points of disagreement in the 2008 and 2009 judgments were, firstly, the appropriateness of an absolute right to protective measures and, secondly, whether the legislation discriminated unfairly against children of different ages. If the High Court's 2008 judgment had been upheld, all child witnesses would have gained a right to testify from separate rooms either with or without intermediaries. Distinctions between children under and 
over 14, and the vague "undue mental stress or suffering" ground, would all have disappeared from our law. In order to meet the new standard of protective measures available to all child witnesses, the government would have been placed under great pressure to improve resources at courts. This would have been a very positive development. The High Court was correct in concluding that the vague requirement of undue mental stress or suffering should be removed. The starting point in every case should rather be a presumption that child witnesses require a protective measure, unless they state otherwise or there are strong counter-considerations.

Whilst the Constitutional Court adopted a different approach, it does provide a higher standard than currently exists. Its ruling that all judicial officers must evaluate the need for protective measures does support careful weighing up of the needs of each individual child. It should be noted that what the Court specifically required was that presiding officers must supplement any shortfall in the parties' canvassing. If necessary, they must conduct a "trial within a trial" inquiry which could even engender calling relevant witnesses themselves. Should they fail to do so, presiding officers run the risk of their decisions being reviewed as procedurally irregular by higher courts. This is likely to encourage them to motivate for adequate resources at their court centres. It can be argued that the Constitutional Court's position, as opposed to the High Court, is more realistically in line with a progressive realisation of services within available resources in a developing country. At present only about $14 \%$ of all criminal courts in South Africa have separate-venue video linkages and intermediaries (2008 case: para 90; see also Jonker \& Swanzen, 2007; Matthias, 2004; Ovens, Lambrechts \& Prinsloo, 2001; Reyneke \& Kruger, 2006).

Although the Constitutional Court's approach to an absolute right to protective measures may be seen as realistic, the same cannot be said for its views supporting discrimination between different ages of child witnesses. This can be seen from its reasoning on the 2007 Amendments. It upheld distinctions between complainants under and over 14. It thus validated the law requiring immediate reasons from courts when refusing protective measures only for complainants under 14. For all children, the time when reasons should be required is clearly before they testify. Firstly, this would help child witnesses to understand legal proceedings (Article 31(b) of the 2005 UN Guidelines on Justice Matters involving Child Victims and Witnesses of Crime). Secondly, having ruled that a child may not receive measures, a judicial officer will hardly be in a good position to be completely objective afterwards. He or she will obviously have to give reasons which justify the refusal. And the main rationale put forward by the Court that the 2007 Amendments underscore the special vulnerability of under-14-year-olds ignores the fact that it entirely leaves out under-14-year-old witnesses who are not complainants. In England distinctions between different categories of child witnesses were abandoned as unfair (Hall, 2009) and the Constitutional Court should have supported the High Court on prevention of discrimination.

Courts should be obliged to keep in mind the international standard that victims of sexual offences, abuse or neglect are an especially vulnerable category. Article 12 of the 1989 UN Convention on the Rights of the Child and article 4(2) of the 1990 African Charter on the Rights and Welfare of the Child both require that children be consulted when important decisions about them are to be taken. Articles 19(f), 20 and 21(b) of the 2005 UN Guidelines require that child witnesses be consulted about protective measures. Thus the position in South Africa ought to be that any child witness of sufficient maturity must be given an opportunity to express his or her wishes about protective measures - including any preference on a particular type. As pointed out by Hall (2009:76), to enable an informed view, children should first be 
shown the courtroom and have alternatives explained. Once the wishes of the child have been established, this should become one factor carefully weighed up by the court in deciding what, if any, protective measures are to be selected.

Concerning the extension of protective measures to children's courts, section 61(2) of the Children's Act, although a move in the right direction, is inadequate. Omission of the option for children simply to give evidence from a separate venue via video link without an intermediary was a grave oversight. Cases may well occur where children prefer this option or when a suitably qualified intermediary is not available. Because children may be just as vulnerable in children's courts as criminal courts, there is no logical reason why options in the former should be more limited. In fact, given its internationally recognised advantages, the possibility of pre-recorded evidence should also have been allowed for in the Children's Act. As Hall (2009:84) and Simon (2006) have pointed out, the greater scope for free-flowing narrative and stress reduction which pre-recording permits means that in some cases it is the best option.

The second shortcoming in section 61(2) is that the possibility of intermediaries in children's courts has been enabled by means of a cross-reference to section 170A of the Criminal Procedure Act. As shown, this raises a technical debate about whether criminal case judgments interpreting section 170A must also in future be applied in children's courts. Tying criminal court and children's court procedures together is likely to lead to complications. It would have been much simpler merely to state in the Children's Act that the appropriateness of utilising an intermediary must be considered by the magistrate whenever a child needs to provide testimony.

\section{SOME IMPLICATIONS FOR SOCIAL WORKERS}

The Constitutional Court's instruction that all child witnesses must in future be assessed before appearing in court, together with the extension of intermediaries to children's courts, has important implications for social workers. Their assessment work relating to protection measures is likely to increase substantially over time. It is therefore important that they take note of the basic criteria listed by the Constitutional Court. As mentioned these are: "age, maturity, degree of independence, feelings and wishes" of the witness and the nature of the case. It is particularly the child's feelings and wishes which have tended to receive insufficient attention in South Africa. When assessing a child who proves to be mature enough, social workers should as a matter of good practice and in accordance with the international instruments cited above always first establish whether the child feels the need for a protective measure. If so, they should then explore which measure the child prefers after there has been an opportunity to see the court facilities. In their pre-hearing documentation social workers should as a standard procedure indicate both what (if any) measure the child desires and what they regard as best, with reasons.

The Constitutional Court's conclusion that legal professionals need to be educated to change their operational culture and become more open to promoting protective measures in accordance with the needs of individual children also has implications for social workers. This is a conclusion supported by recent findings in England (Hall, 2009). Social workers should use their influence as assessors of protective measures. As a form of child advocacy, they should seize every opportunity to encourage legal professionals to consider utilising protective measures and consulting directly with children on how they would like to give evidence. The new party status for social workers in children's courts will even allow welfare organisations to 
require a review by a higher court, if protective measures are not properly considered by magistrates. To increase the available options for children, social workers, as key role players, should more generally advocate for improvements in the law to allow the possibility of prerecorded evidence for criminal cases and the introduction of more than merely one protective measure in the children's courts.

\section{REFERENCES}

DIRECTOR OF PUBLIC PROSECUTIONS, TRANSVAAL V MINISTER FOR JUSTICE AND CONSTITUTIONAL DEVELOPMENT AND OTHERS CCT 36/08 [2009] ZACC 8.

HALL, M. 2009. Children giving evidence through special measures in criminal courts: progress and problems. Child and Family Quarterly, 21(1):65-87.

JONKER, G. \& SWANZEN, R. 2007. Intermediary services for child witnesses testifying in South African criminal courts. Sur, São Paulo, v.3. [Online] Available: <http://socialsciences.scielo.org/scielo.php?script=sci_arttext\&pid=S1806-64452007000

100005\&lng=en\&nrm=iso $>$. [Accessed: 10/12/2009].

MATTHIAS, C.R. 2004. Is the court-survival lifeline for children working? Some qualitative research findings on the intermediary system. The Social Work Practitioner-Researcher, 16(3):297-312.

MELLIS, V. (n.d.). Prosecuting violence against children in South Africa. Unpublished paper.

MULLER, K. \& VAN DER MERWE, A. 2004. The sexual offences prosecutor: a new specialisation. Journal for Juridical Science, 29(1):135-151.

MULLER, K. \& VAN DER MERWE, A. 2005. Judicial management in child abuse cases: empowering judicial officers to be "the boss of the court". South African Journal of Criminal Justice, 18(1):41-55.

MULLER, K. \& TAIT, M. 1999. Little witnesses: a suggestion for improving the lot of children in court. THRHR, 62(2):241-258.

OVENS, M., LAMBRECHTS, D. \& PRINSLOO, J. 2001. Child witnesses in the criminal justice system. Acta Criminologica, 14(2):25-40.

REPUBLIC OF SOUTH AFRICA (1 April 2010). Consolidated Regulations Pertaining to the Children's Act, 2005 Government Gazette No 33076, Government Printer.

REPUBLIC OF SOUTH AFRICA. Children's Act 38 of 2005.

REPUBLIC OF SOUTH AFRICA. Constitution, Act 108 of 1996.

REPUBLIC OF SOUTH AFRICA. Criminal Law (Sexual Offences and Related Matters) Amendment Act 32 of 2007.

REPUBLIC OF SOUTH AFRICA. Criminal Procedure Act 51 of 1977.

REPUBLIC OF SOUTH AFRICA (31 March 2010). Regulations relating to Children's Courts and International Child Abduction Government Gazette No. 33067, Government Printer.

REYNEKE, J.M. \& KRUGER, H.B. 2006. Sexual offences courts: better justice for children. Journal for Juridical Science, 31(2):73-107.

S V MOKOENA; S V PHASWANE 2008 (2) SACR 216 (T). 
204

SCHUTTE, F. 2005. Child witnesses in the criminal justice system in South Africa: an overview of proposals for reform. [Online] Available: www.childjustice.org/docs/schutte 2005.pdf. [Accessed: 10/12/2009].

SIMON, J. 2006. Pre-recorded videotaped evidence of child witnesses. South African Journal of Criminal Justice, 19(1):56-78.

SOUTH AFRICAN LAW COMMISSION 2002. Sexual Offences: Process and Procedure. Project 107, Discussion Paper 102.

UNITED NATIONS. 2005. Guidelines on Justice Matters involving Child Victims and Witnesses of Crime.

Prof Carmel $R$ Matthias, School of Social Work and Community Development, University of KwaZulu-Natal, Durban, South Africa. 